\title{
Sediment Transport Monitoring and Short Term Modeling in the Okavango Delta, Botswana
}

\author{
Journal Article \\ Author(s): \\ Milzow, Christian; Tshekiso, Otlaathusa; Kgotlhang, Lesego; Kinzelbach, Wolfgang \\ Publication date: \\ 2010 \\ Permanent link: \\ https://doi.org/10.3929/ethz-b-000020449 \\ Rights / license: \\ In Copyright - Non-Commercial Use Permitted \\ Originally published in: \\ Wetlands 30(3), https://doi.org/10.1007/s13157-010-0042-x
}




\title{
Sediment Transport Monitoring and Short Term Modeling in the Okavango Delta, Botswana
}

\author{
Christian Milzow • Otlaathusa Tshekiso • \\ Lesego Kgotlhang • Wolfgang Kinzelbach
}

Received: 1 June 2009 /Accepted: 23 December 2009/Published online: 4 May 2010

(C) Society of Wetland Scientists 2010

\begin{abstract}
The Okavango Delta of northern Botswana comprises large wetlands that spread over an alluvial fan of $150 \mathrm{~km}$ in length. Only part of the fan is covered with wetlands but the repeated shifting of the zones prone to inundation has led to a regular distribution of sediments and eventually to the formation of a smooth fan surface. We conducted repeated solute and bedload transport measurements at the inlet and within the wetlands proper to quantify sediment input and channel aggradation rates. The relationship between flow velocity and bedload transport was used to simulate channel erosion and aggradation, and a bedload transport component was built into a numerical hydrological model of the Okavango Delta. The model was used to assess the impact of a hypothetical dam in the upstream of the wetlands on channel bed elevations and the distribution of flooded areas. Our results suggest that the contribution of solute inputs to the overall sediment accumulation of the fan has been overestimated relative to bedload inputs. The numerical simulations reveal that a dam would have an impact on channel elevations only in its immediate downstream, but an impact on the distribution of flooding would be felt over the entire wetland system.
\end{abstract}

Keywords Bedload Channel aggradation. Numerical modeling $\cdot$ Wetland dynamics

C. Milzow $(\bowtie) \cdot$ L. Kgotlhang $\cdot$ W. Kinzelbach Institute of Environmental Engineering, ETH Zurich, 8093 Zurich, Switzerland

e-mail: christian.milzow@alumni.ethz.ch

O. Tshekiso $\cdot$ L. Kgotlhang

Department of Water Affairs, Government of Botswana,

Gaborone, Botswana

\section{Introduction}

The opening of the western branch of the East African Rift in northern Botswana has led to the formation of the Okavango Graben in which the Okavango River discharges into its terminal wetlands (Reeves 1972). These wetlands are commonly referred to as the Okavango Delta (Fig. 1) even though they do not represent a delta in strict terms because channels do not discharge into a standing water body. Sedimentologically it is best viewed as a terminal alluvial fan system (Bridge 2003). Dincer et al. (1987) associate tectonic events of the Miocene (23.03-5.33 Ma BP) with the initiation of the fan.

The Okavango River originates in the Angolan highlands, which present a subtropical and humid climate with annual precipitation of up to $1,300 \mathrm{~mm} /$ year. After running through southern Angola and the Namibian Caprivi Strip the River reaches the Okavango Delta in north-western Botswana where the climate is semi-arid with an average annual precipitation rate of $450 \mathrm{~mm} /$ year. Distinct dry and wet seasons in the headwater region result in a marked seasonality of river discharge with annual flood peaks between $400 \mathrm{~m}^{3} / \mathrm{s}$ and $900 \mathrm{~m}^{3} / \mathrm{s}$ and baseflow of approximately $150 \mathrm{~m}^{3} / \mathrm{s}$. In the wetlands of the Okavango Delta approximately $94 \%$ of the discharge is lost by evapotranspiration, an estimated 3\% infiltrates into the regional groundwater system, with the remaining 3\% leaving the wetland system as ephemeral surface outflows through the Boteti River, which, however, runs dry after a few tens of kilometres (Dincer et al. 1978). The high losses through evapotranspiration can be differentiated into direct evapotranspiration from open water surfaces and aquatic vegetation, and transpiration of water infiltrated in channels and floodplains by the vegetation of the multitude of islands characteristic of the wetlands (Dincer et al. 1976; Wolski 


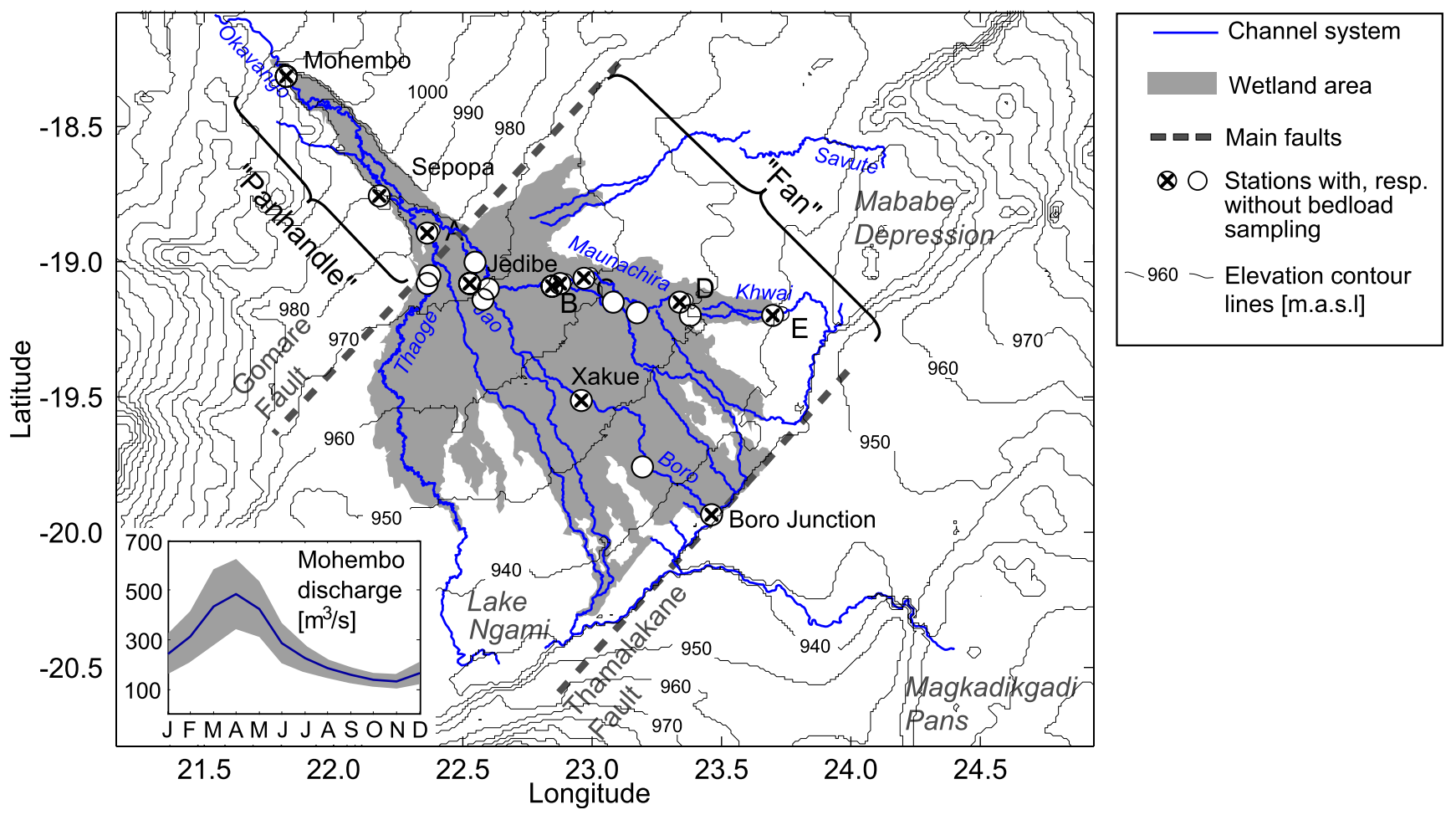

Fig. 1 Okavango Delta area with locations of stations that are referred to in the text. Note the fan shaped surface in the wetland area. The lowest elevated zones are ephemeral and past outflow zones from the wetlands. Lake Ngami is flooded by approximately $50 \%$ of the annual floods, the Mababe Depression and the Magkadigkadi Pans are not flooded under present climate conditions by channels of the

and Savenije 2006; Ramberg et al. 2006b). Primary and secondary production of organic compounds in the wetlands is strongly influenced by the hydrological conditions and their inter-annual variability (Lindholm et al. 2007).

The special hydrological conditions of the Okavango Delta allow for a large variety of ecosystems. Diversity of flora and fauna (Ramberg et al. 2006a) form a large biodiversity pool which is of global importance. The Okavango Delta is included in the Ramsar List of Wetlands of International Importance (UNESCO 1971).

In 2003 the national power utility of Namibia proposed to construct a $20 \mathrm{MW}$ hydropower dam in the Caprivi Strip, upstream of the Okavango Delta (NamPower 2003). The impact on flooding was found to be minor due to the small size of the reservoir relative to discharge (the storage volume of the dam amounting to about $12 \mathrm{~h}$ of runoff at mean discharge). However, the scheme has raised concerns about the retention of sediments. The present study represents the first opportunity to evaluate the consequence of sediment retention by such a dam.

Measurements of sediment transport including bedload, suspended load and solutes within the Okavango Delta have previously been conducted on several isolated
Okavango, but the lowest point of the Mababe depression, the Savuti Marsh, is flooded sporadically from the north by a tributary of the Zambezi River. Part of the displayed channel system is not currently active. The inlet shows mean monthly discharges at Mohembo computed over the period from 1933 to 2008 and the range of minus to plus one standard deviation occasions by the Okavango Research Group of the University of Witwatersrand in Johannesburg, with a focus on the Okavango-Nqoga-Maunachira system (McCarthy et al. 1991, 1992). However, the studies are limited in that they are based on 12 bedload measurements spread along the system during low discharge in December 1987, with only two measurements taken during moderate discharge periods in April 1989. The extension of such measurements into a regular monitoring has always been desirable. In this article we present the results of solute and bedload measurements carried out over a period of 3 years. We augment the results of McCarthy et al. $(1991,1992)$ in several ways:

1) A regular monitoring of bedload and solutes at several stations is conducted to gain more understanding of the temporal dynamics of sediment transport and channel avulsion in the wetlands.

2) Bedload measurements during high discharge events are conducted to improve the rating curve linking bedload transport to flow velocities.

3) Mass balance and numerical modeling is used to better understand sediment fluxes and the spatial distribution of channel aggradation rates. 
4) The impact of a hypothetical engineering intervention, the construction of a dam upstream of the Okavango Delta is evaluated by numerical modeling.

\section{Sedimentological Processes}

Sediment transfers play a crucial role in varying flooding patterns in the Okavango Delta. Being an alluvial fan, all parts of the fan area have, in the past, been subject to flooding and sediment deposition. An indication of timescales, over which channel avulsion occurs, is obtained through the measured channel base aggradation rates of up to $0.017 \mathrm{~m} /$ year (McCarthy et al. 1992) and an estimated life span in the order of a hundred years (McCarthy et al. 1988) for a particular channel, the Nqoga. McCarthy et al. (1992) further estimate that aggradation rates can be up to $0.05 \mathrm{~m} /$ year in distal reaches of the Nqoga. It is, however, uncertain if these findings are applicable to other distributaries.

Flows in the wetlands are a combination of channel and floodplain flows with very small flow velocities for the latter. Channel beds consist of fine- to medium-grained sand with a relatively uniform grain-size of $0.35 \mathrm{~mm}$ (McCarthy et al. 1991). Channel margins are densely vegetated by grasses (Pennisetum glaucocladum), reeds (Phragmites mauritianus), and the semi-floating sedge Cyperus papyrus (Ellery et al. 2003). When water flows from the main channels onto the floodplains, the dense vegetation filters bedload and suspended load. Particle sediments are therefore almost completely deposited in the channels with solutes reaching the floodplains where chemical sedimentation occurs. Clastic, inorganic sediment transport occurs mainly as bedload and is limited to the channel system. Given the long time scales involved since the onset of the fan formation and climate variations (Lancaster 1979), it is likely that discharge and sediment characteristics have varied considerably throughout time.

The abundant vegetation on channel margins stabilizes the channel position. The continuous avulsion of channels over the fan is prevented, with aggradating channels developing bed elevation higher than the surrounding floodplain topography. Eventually lateral hydraulic gradients promote avulsion and the formation of new channel locations (McCarthy et al. 1988, 1992). Channel switching can occur quickly, generating considerable changes in geomorphology in only a few years. This avulsion process is likely to be limited to the fan part of the wetlands. In the proximal Panhandle area, stream power is larger, generating slow but continuous shifting of the channels.

The downstream decrease in discharge and transport capacity of the bifurcating feeder channels leads to the deposition of all incoming bedload and suspended sediments. In addition, evapoconcentration causes precipitation of the incoming solutes. Deposition rates in combination with vegetation growth are driving the life spans of individual distributaries. Over geological time scales, channels and floodplains regularly shift, resulting in the creation of a regular, low relief alluvial fan surface (McCarthy et al. 1986; Wolski and Murray-Hudson 2006), which consists of alluvial sediments of the Okavango River and additional aerosol inputs (Garstang et al. 1998). The thickness of the fan varies between $30 \mathrm{~m}$ and $400 \mathrm{~m}$ (Kgotlhang et al. 2006).

Neo-tectonics contributes to avulsion as large scale tilting of the Okavango Delta generates variations in channel slope (Pike 1970; Bauer et al. 2006; Milzow 2008). Smaller faults also locally deflect individual channels of the wetlands (McCarthy et al. 1993). The relative importance of tectonics and sedimentation for flow distribution changes observed in the past is not yet fully understood.

Channel stabilization measures such as channel dredging and papyrus clearing have been used to prevent the natural avulsive behavior of the system (Ellery and McCarthy 1998). Channel stabilization measures have not, however, been particularly successful. Ellery et al. (1995) show vegetation blockages to be a symptom and not a cause of channel decline and abandonment. The process of frequent channel avulsion is a major problem and has major impact on human settlement and activity.

The department of Water Affairs of Botswana has carried out intensive measurements of water levels and discharge over the last few decades. This program has led to a very good understanding of the current flow distribution and the seasonality of the Okavango Delta system. It indicates changes in flow distribution that are presently occurring (Wolski and Murray-Hudson 2008). Underlying mechanisms of change are sediment transport coupled with vegetation growth and neo-tectonics. Despite its importance, sediment transport and in particular bedload transport, which is the main form of sediment transport responsible for channel avulsion in the Okavango Delta, has been studied only marginally in comparison to water discharge.

\section{Material and Methods}

\section{Bedload Monitoring}

Channels of the Okavango Delta represent difficult environments for bedload transport monitoring. The majority of bedload transport occurs in perennial, several meter deep channels with base elevations changing with time, which 
does not allow for the use of bedload traps. Even though bedload of the Okavango Delta is characterized by dunes and ripples, the use of bedform movement techniques (e.g. nuclear gauges or side scanning sonars) to quantify transport is made impossible by the lack of appropriate anchor sites to install instruments. Channel margins contain extensive blankets of floating vegetation that give only limited stability to anchor ropes. Without the availability of bridges and lack of reliable anchorage sites, the only viable option in this study was the use of pressure difference samplers. Helley-Smith type samplers were employed from a boat anchored with ropes on channel bank vegetation. Sampling points were arranged in a grid pattern over the area of interest. Five bedload transport measurements separated by 1 or $2 \mathrm{~m}$ streamwise distance were made in each lateral sampling site. A depth-integrated flow velocity (with samplings at $20 \%, 50 \%$, and $80 \%$ of depth) was measured at the upstream end of these five points. The average of the five individual measurements in combination with the depth-integrated flow velocity is hereafter referred to as one point measurement. Depending on channel width, approximately 10 point measurements were taken at each surveyed cross section.

A rating curve linking depth-averaged flow velocity $(V)$ in $\mathrm{m} / \mathrm{s}$ to bedload transport $\left(Q_{\text {bedload }}\right)$ in $\mathrm{kg} / \mathrm{m} / \mathrm{s}$ is fitted using all point measurements. We are using an exponential function as did McCarthy et al. (1991) with parameters $a$ and $b$ :

$O_{\text {bedload }}=a \cdot V^{b}$

A handheld sampler was initially used but it was replaced with a cable-suspended sampler for measurements at high flows (see Table 1 for specifications of the samplers). Comparative measurements with both instruments resulted in only small differences of transport rates. In total, 38 bedload transport measurements have been conducted. Some measurement stations were sampled repeatedly in 2006 and 2007 with approximately monthly intervals to study the temporal change of bedload transport. The locations of the stations were selected where possible in the center of regular and straight channel sections.

Bedload samples were taken at the stations for further analysis. The samples were dry sieved through a stack of 12 sieves with mesh openings of $1,000 \mu \mathrm{m}, 800 \mu \mathrm{m}, 630 \mu \mathrm{m}$, $500 \mu \mathrm{m}, 400 \mu \mathrm{m}, 315 \mu \mathrm{m}, 250 \mu \mathrm{m}, 200 \mu \mathrm{m}, 160 \mu \mathrm{m}$, $125 \mu \mathrm{m}, 100 \mu \mathrm{m}$, and $80 \mu \mathrm{m}$. For each station, bed material samples from points regularly spaced over the channel width were combined to calculate mean station grain-size distributions.

\section{Solute Monitoring}

Along with bedload monitoring, 24 water samples were taken in July and August 2005 at various locations spread over the wetlands. An additional 8 samples were taken during the period from October 2005 to December 2006 at the Mohembo station. To determine ion concentrations, the samples were analyzed by means of ion chromatography with a detection limit of approximately $0.1 \mathrm{mg} / \mathrm{l}$. A Bran + Luebbe AutoAnalyzer 3 was used to determine silica concentrations using a continuous flow application method (Bran + Luebbe 1999).

At Mohembo station, at the inlet to the Okavango Delta, ion and silica concentrations are multiplied with measured discharge and the resulting ion and silica fluxes are then transformed into a potential depositional mass by accounting for the atomic weight of the respective deposits. In order to calculate sediment accumulation on the fan, solute fluxes to the regional groundwater system must be subtracted from these potential depositional masses. The inflow to the Okavango Delta has been recorded daily since 1975 by propeller measurements at the Mohembo Station, with monthly discharges being available since 1933 (Sefe 1996).

\section{Bedload Transport Modeling}

In order to appreciate intensity and spatial distribution of current aggradation rates in the channels of the Okavango Delta, a hydrological model of the wetlands (Milzow et al. 2009) was adapted to incorporate bedload transport. The model was further applied to study impacts of engineering interventions in the Okavango Delta. The relation of flow velocities to bedload transport observed in this study (Section Bedload transport) is used to simulate bedload transport. The hydrological model by Milzow et al. (2009)
Table 1 Specifications of the pressure difference bedload samplers

\begin{tabular}{lll}
\hline & Handheld (Rickly, Model 8015) & Suspended (US-BL 84) \\
\hline Type & Helley-Smith & Helley-Smith \\
Nozzle opening & $0.076 \mathrm{~m} \times 0.076 \mathrm{~m}$ & $0.076 \mathrm{~m} \times 0.076 \mathrm{~m}$ \\
Nozzle expansion ratio & 3.22 & 1.40 \\
Bag mesh opening size & $60 \mu \mathrm{m}$ & $60 \mu \mathrm{m}$ \\
Bag opening ratio & $35 \%$ & $35 \%$ \\
Weight & $1.8 \mathrm{~kg}+$ rods & $15 \mathrm{~kg}$ \\
\hline
\end{tabular}


is based on the MODFLOW software that is an open source code developed by the U. S. Geological Survey. It is a three-dimensional finite-difference ground water model with modular structure. This structure allows it to be easily expanded by including new packages (Harbaugh et al. 2000). Such packages were provided to include surface waters and routing of floods as well as exchange between surface and groundwater.

We developed a bedload transport package for MODFLOW, hereafter referred to as BLT package, which routes bedload downstream as a function of channel widths and flow velocities simulated by the stream flow routing package SFR2 (Niswonger and Prudic 2005). It assumes that the transport is never supply limited, and does not account for armoring effects, nor for variable grain-size. These assumptions are valid for the Okavango Delta where bedload is of relatively uniform grain-size and the bases of the main distributor channels are free of aquatic vegetation cover due to low nutrient concentrations. No occurrence of bedrock as channel base is found in the Okavango Delta. At channel bifurcations, the bedload flux is split according to the simulated transport capacities in the first reaches of the downstream segments. If, for the end of a segment, no downstream connecting segment is specified, the sediment cannot leave the last reach. As a boundary condition, the first reach of every segment can be set to either keep a constant channel base elevation even when bedload is lost downstream, or can be set to have variable channel base elevation. All consecutive reaches necessarily have variable base elevations. The BLT package includes the option to prevent the creation of sinks. If according to the transport capacity, sufficient sediment could be removed from a certain reach to form a sink, the actually transported sediment amount is truncated to avoid a sink being created.

New reach elevations are found iteratively (Fig. 2), which is necessary because of channel junctions and bifurcations that make it impossible to loop through all reaches in a strict upstream to downstream order. Also, it can occur that bedload is not routed from one reach (A) to the next reach (B) to avoid a sink in the first reach (A). In a later calculation of the same iteration bedload is routed to the first reach (A) from upstream, thus allowing for more bedload to be routed from the first reach (A) to the second one (B).

The bedload transport capacity $\left(Q_{\text {bed,cap }}\right.$ in $\left.\mathrm{m}^{3} / \mathrm{s}\right)$ from one reach $i$ to the downstream reach $i+1$ is calculated from the velocities $(V$ in $\mathrm{m} / \mathrm{s})$ in both reaches and the width ( $W$ in m) of reach $i$ :

$Q_{b e d, c a p}=a \cdot\left(\frac{V_{i}+V_{i+1}}{2}\right)^{b} \cdot W_{i}$

where $\mathrm{a}$ and $\mathrm{b}$ are the parameters of Eq. 1 .

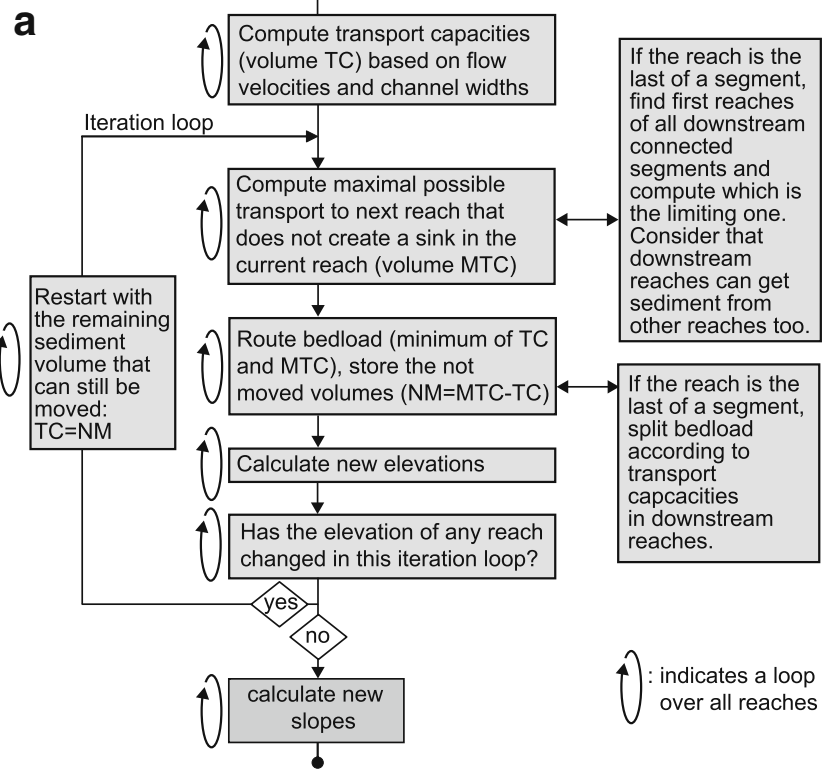

b

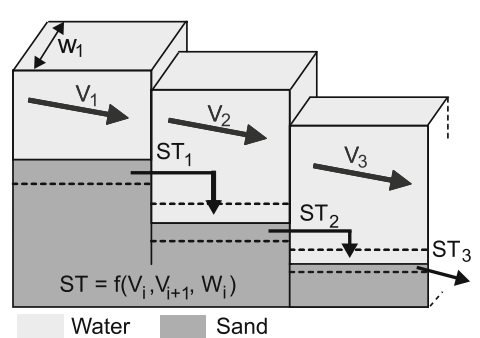

Fig. 2 a Flowchart of the BLT bedload transport package. b Scheme of three consecutive reaches. V is the flow velocity and ST is the sediment transport

The BLT package is implemented into the MODFLOW code at the time step level. At the end of every time step, bedload transport rates are calculated and elevations and slopes of all reaches are set accordingly. The time step in the model of the Okavango Delta is $8 \mathrm{~h}$.

\section{Results and Discussion: Monitoring}

\section{Grain-Size Distribution}

Along the central channel system (the Okavango-Boro system), a general decrease in grain-size is observed from upstream to downstream (Fig. 3). A deviation from this trend occurs at Sepopa station, created by the bypassing of a section of the main Okavango (on which Sepopa is located) by the Filipa channel. The Filipa channel flows parallel to the Okavango for approximately $30 \mathrm{~km}$, and carries the largest share of discharge before rejoining the main Okavango channel.

Despite the observed regular downstream trend, the grain-size variability within single stations was found to 


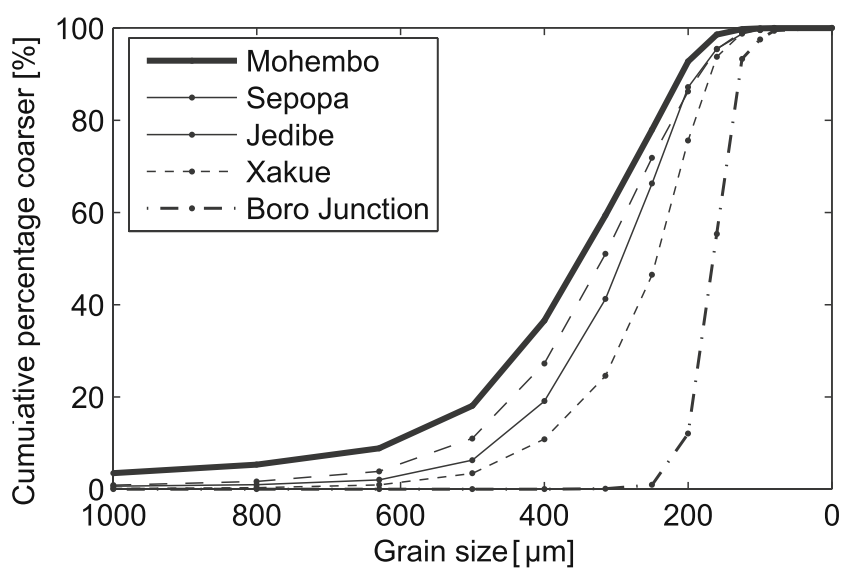

Fig. 3 Station averaged grain-size distribution for stations along the Okavango-Boro channel system. See Fig. 1 for location of the stations

be of the same magnitude or even larger than the changes in longitudinal direction. A clear lateral trend is found for most stations with $D_{50}$ values increasing monotonically from one bank to the other (Fig. 4). This lateral trend is however not necessarily directed with smaller grain-sizes towards the point bar side of the cross sections. Sepopa station is located after the first $300 \mathrm{~m}$ of a $500 \mathrm{~m}$ long straight channel section. Smaller $\mathrm{D}_{50}$ values are found on

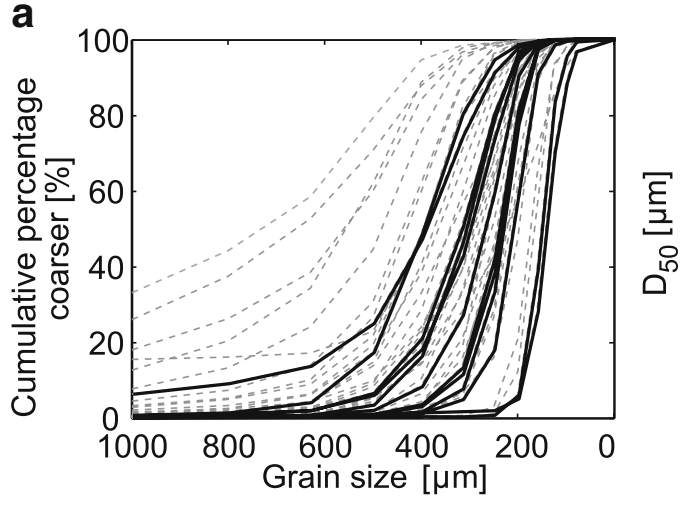

b

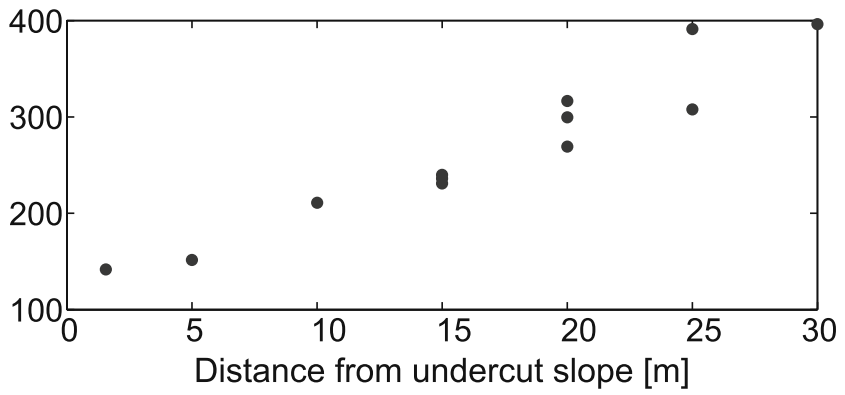

Fig. 4 a Grain-size distribution of samples taken at Sepopa station (full lines) in comparison to samples taken at all stations in the Okavango Delta (dashed lines). b Lateral distribution of the $\mathrm{D}_{50}$ grainsize at Sepopa the left channel bank, which is the undercut slope relative to the downstream channel bend. Shallower water depths were also measured on the left channel side, indicating that processes at smaller scales than the $500 \mathrm{~m}$ spaced bends are responsible for the lateral differences in $\mathrm{D}_{50}$ grain-size.

Bedload Transport

\section{Bedload Transport to Flow Relation}

The measured relation between depth-averaged flow velocity and bedload transport is shown in Fig. 5a. The high variability in the data was expected because measurements were conducted in a natural system with disturbances and not in a laboratory flume. The effect of channel properties (e.g. side walls, uneven channel bed) and measurement conditions (e.g. moving boat, handheld sampler) cannot be excluded. Still, the data clearly show the exponential shape of the relation. When applying the exponential relation of Eq. 1 to the data, a value of 3.3 is obtained for the exponent $b$ and the multiplier $a$ has the value 0.07 . The coefficient of determination $\mathrm{R}^{2}$ of the fit is 0.61 and the root mean squared error is 0.019 . Additional measurements during high discharge would significantly improve the characterization of the relationship.

The variability may further be reduced by studying the relation between mean cross sectional flow velocity to specific bedload transport. The rating curves differ insignificantly in the densely covered velocity range up to $0.9 \mathrm{~m} / \mathrm{s}$. Above $1 \mathrm{~m} / \mathrm{s}$ however the rating curves differ strongly, the exponent $b$ being higher for the fit of the cross sectional means. The rating curve fitted on point measurements appears to be more consistent because cross sectional means consist of different numbers of point measurements, which leads to an inconsistent weighting of the values.

McCarthy et al. $(1991,1992)$ conducted similar measurements at low discharge conditions in December 1987/ January 1988 and in December 1988/January 1989, as well as two measurements at moderate discharge conditions in April 1989. The rating curve by McCarthy et al. (1992), fitted on cross sectional means, differs from the results of this study by predicting higher sediment transport. The logarithmic representation in Fig. 5b shows these differences more clearly. The rating curves are fitted with a least squares fit. The fit is applied to the data before taking the logarithm so that the high flow measurements are not underweighted.

A comparison of the measured bedload transport rates with laboratory derived formulae is difficult because the wetlands of the Okavango Delta represent an extraordinarily flat environment. With a mean channel slope of $0.19 \%$, the channels are by a factor of 2 flatter than the range of application of usual laboratory derived sediment transport formulae (e.g., Meyer-Peter and Müller 1948: 0.4\%o to 

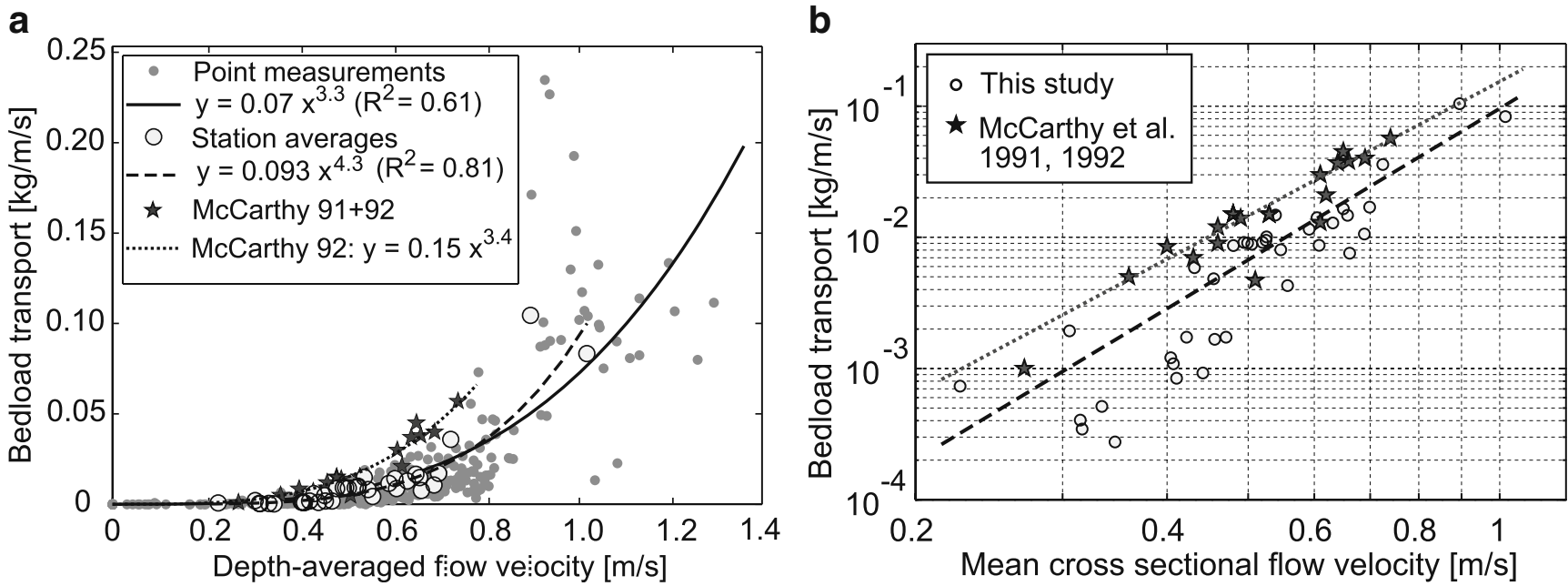

Fig. 5 a Relation between depth-averaged flow velocity and bedload transport. b Logarithmic representation of channel cross sectional averages

$2.3 \%$ ). Also, the sediment (median grain-size $0.35 \mathrm{~mm}$ ) is one to two orders of magnitude smaller than the gravel for which the Meyer-Peter and Müller formula was derived. Einstein's (1950) approach, which is based on the probabilities of movement for individual particles, is more promising for the Okavango Delta. In principle it is valid for all ranges of slopes and grain-sizes, but because some constants have been derived under specific conditions, the range of validity covers only fine-gained sediments in low gradient channels. This range corresponds to the Okavango Delta. But when applying Einstein's formula to the observed channel slopes and water depths (as approximation for the hydraulic radius) it produces transport rates three times as large as the measured values. We hypothesize that the considerable overestimation by Einstein's formula is due to the steep peat sidewalls of the channels, which absorb part of the stream power.

\section{Spatial and Temporal Variability of Bedload Transport}

Within this study, bedload transport in channels of the Okavango Delta has been monitored repeatedly at several stations for the first time (Fig. 6). For the Sepopa and Jedibe stations bedload transport was monitored approximately monthly over the entire flood cycle from November 2005 to October 2006. We found that during the flood cycle, the discharge varied by a factor of less than 2 for Sepopa and Jedibe, whereas bedload transport varied by a factor of approximately 35 . Effective bedload transport was thus limited to the months of February 2006 to July 2006. We found very regular regimes of bedload transport that monotonically rose and then fell with mean flow velocities (discharge/flow area).

Because of steep channel margins stabilized by vegetation, channel width stays constant throughout the year. For the Sepopa station (Fig. 6b), it is seen that the smooth temporal variation of discharge is not reproduced by the mean flow velocity. Mean flow velocity and bedload transport stabilize at approximately $0.5 \mathrm{~m} / \mathrm{s}$ and $0.35 \mathrm{~kg} / \mathrm{s}$, respectively.

The data acquired at Mohembo station in April 2007 represent bedload measurement during highest discharge and flow velocities that have so far been measured in the Okavango channels. The annual maximum inflow, which
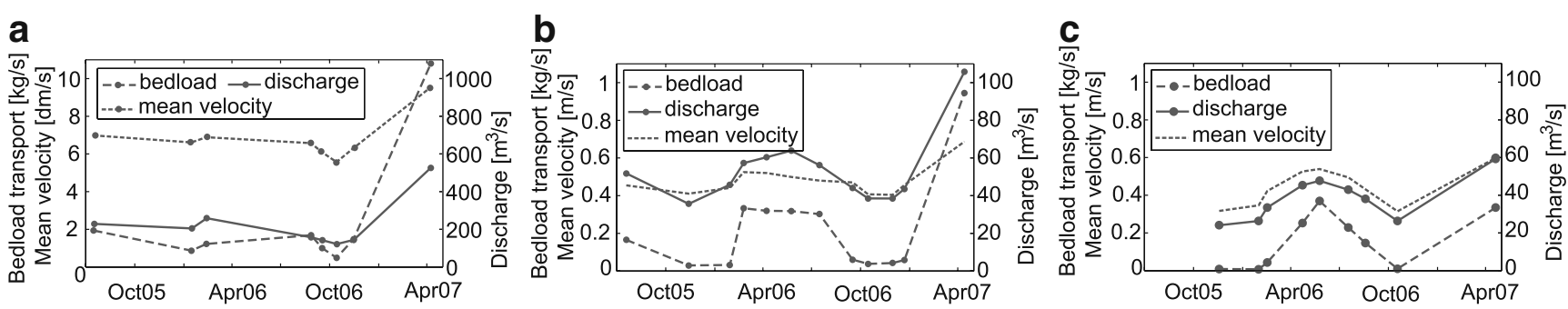

Fig. 6 Total bedload transport, cross sectional mean flow velocity and discharge at three measurement stations: a) Mohembo (channel width= $115 \mathrm{~m}$ ), b Sepopa (channel width=35 m), and $\mathbf{c}$ Jedibe (channel width= $26 \mathrm{~m}$ ). Note the factor 10 of change in the vertical scale for discharge and total bedload transport between Mohembo and the other stations. At the Mohembo station, the lack of data during the flood peak results from the unavailability, in 2006, of a suspended sampler and the impossibility to use the handheld sampler at very high discharge events 
was recorded on the same day by the Department of Water Affairs of Botswana (DWA), was $750 \mathrm{~m}^{3} / \mathrm{s}$. At the bedload measurement location $(5 \mathrm{~km}$ downstream from the DWA measurement location), the average of two consecutive discharge measurements was $530 \mathrm{~m}^{3} / \mathrm{s}$, with depthaveraged flow velocities on the order of $1 \mathrm{~m} / \mathrm{s} ; 10.8 \mathrm{~kg} / \mathrm{s}$ of bedload were transported through the cross section at that time.

By using long time series of flow velocities and discharge available for Mohembo station at the inlet to the Okavango Delta, a relationship was calculated between the total discharge and the flow velocities at each position along the cross section. This is possible as the location of the channel is unlikely to have varied over the last few decades, its location being constrained by bedrock on its western side. From the derived flow velocities the bedload transport is calculated using Eq. 1. The integration of the bedload transport rates over time yields the total amount of unconsolidated bedload that enters the Okavango Delta on average as 120,000 tonnes/year.

\section{Solute Concentrations}

The analysis of water samples reveals that the solute content of the Okavango water is generally very low, with main components being silica (63\%), calcium (16\%), sodium $(9 \%)$, potassium $(7 \%)$, and magnesium $(4 \%)$. For many of the samples the concentration of sulfate was around the detection limit of $0.1 \mathrm{mg} / \mathrm{l}$. At such concentrations, sulfate cannot be measured precisely by ion chromatography. Concentrations of nitrate, phosphate, lithium, and ammonium were, with few exceptions, also below the detection limit.

The measured concentrations in the samples taken in July and August 2005 along the channel system show a general increase in downstream direction, which is an indicator of evapoconcentration in the wetlands (Fig. 7). The temporal change of ion concentrations at the inlet to the wetlands in Mohembo (Fig. 8) shows a seasonal fluctuation of concentrations. Ion concentrations do not seem to be directly linked to discharge rates in November and December 2006. Concentrations increase before the discharge increases. It is also observed that concentration time curves are different for each ion. The onset of precipitation at the beginning of the rainy season is likely to wash out fines and dissolve more ions than later precipitation events. The limited number of samples does not allow a comprehensive study of the temporal dynamics for each ion concentration. Therefore, in order to calculate the annual input for each ion, the mean concentration is multiplied with an inflow of $292 \mathrm{~m}^{3} / \mathrm{s}$, which is the mean measured flow for the period from 1933 to 2006. Potential
Fig. 7 Spatial distribution of ion and silicate concentrations in July and August 2005. The diameters of the dots are proportional to measured concentrations
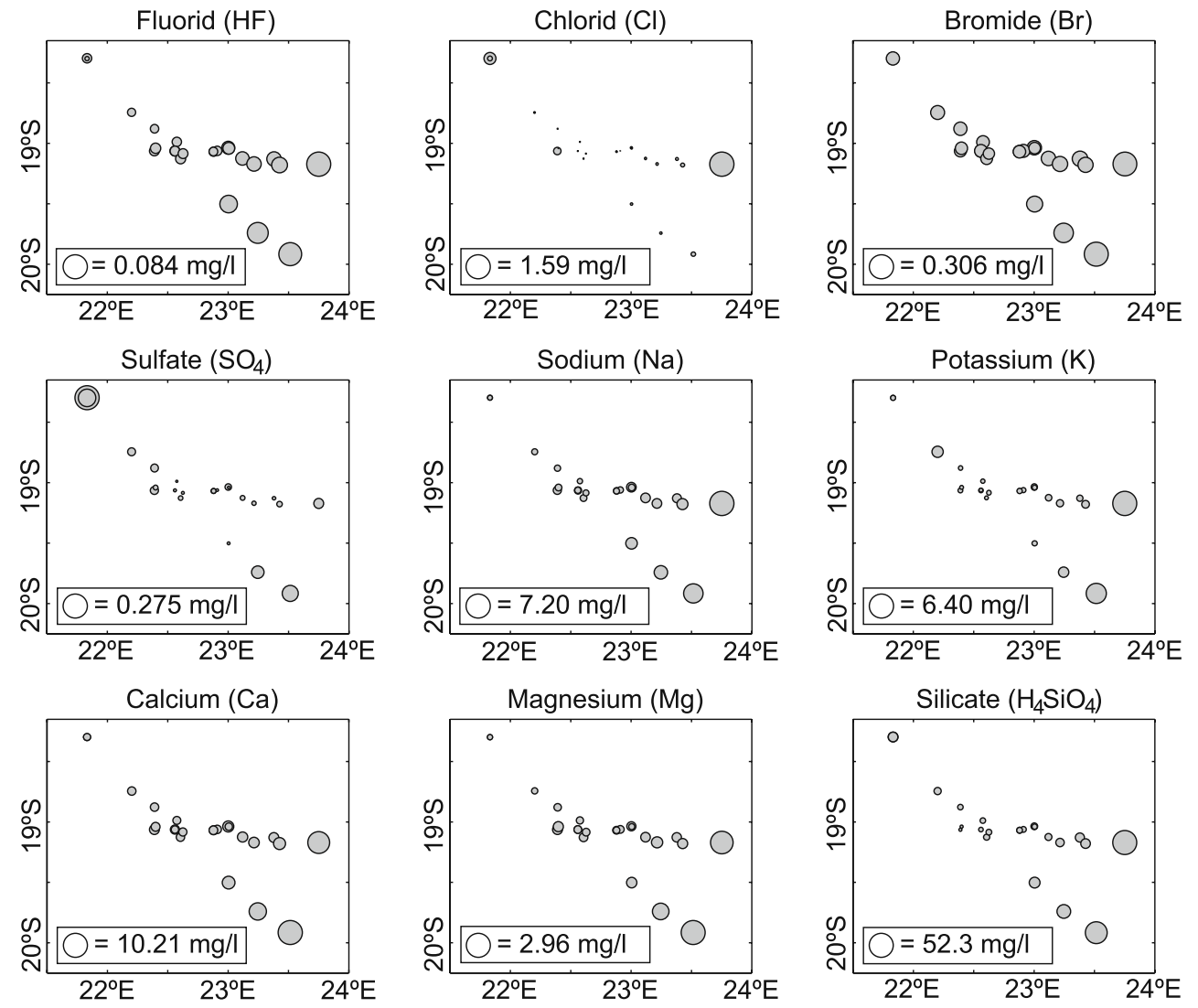


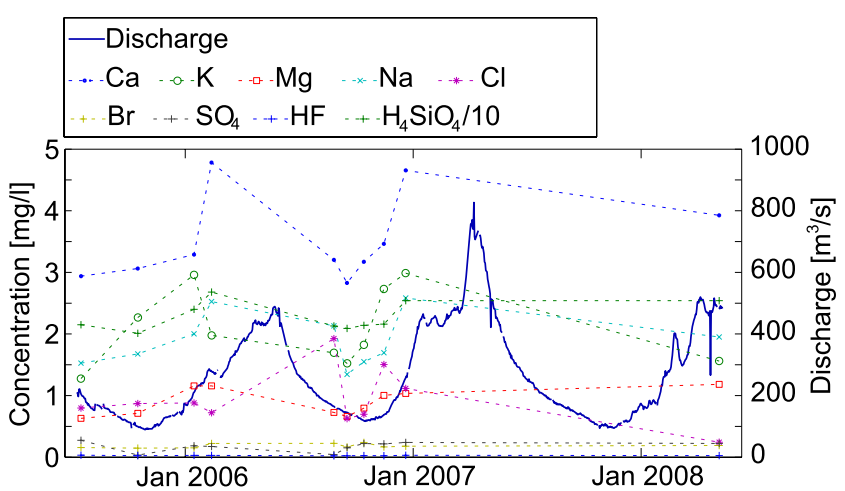

Fig. 8 Temporal change of the ion and silicate concentrations together with measured discharge for Mohembo station, situated at the inlet to the wetlands

depositional masses of respective resulting deposits are shown in Table 2. The masses represent potential amounts because of ground-water outflows to the regional groundwater system. These outflows - although small in flow rate-are likely to contain high concentrations of the solutes, as discussed below.

The total potential mass of deposits of 316,900 tonnes per year is dominated by silica. This value is $31 \%$ below the 457,400 tonnes estimated by McCarthy and Metcalfe (1990) based on a single water sample in August 1975. Uncertainty in our results may originate mainly from the relation between discharge and concentration, which we have crudely approximated by using a mean concentration. In reality, a hysteretic effect may be expected, with higher concentrations during rising water levels, and lower concentrations in the falling limb of the flood. We can estimate an upper boundary of the solute inputs by using the maximal concentrations for each ion instead of mean values. The resulting total mass input of 407,100 tonnes is still $11 \%$ below the value estimated by McCarthy and Metcalfe (1990).

\section{Sediment Mass Balance}

An approximate sediment mass balance can be derived for the Okavango Delta when, in addition to the discussed inputs, outflows from the system are considered. By means of measured discharge and solute concentrations in the Boteti channel, McCarthy and Metcalfe (1990) calculated a solute mass flux of approximately 30,000 tonnes per year through that channel. Whether this is a loss to the Okavango Delta system depends on the choice of system boundary position, with the Boteti channel flowing only a short distance before drying out. Considerably more solutes might be leaving the system by flows of saturated brines to the regional groundwater system. McCarthy and Metcalfe (1990) calculate that with a saturated sub-surface outflow amounting to $2.9 \%$ of the inflow, 180,000 tonnes of solutes are removed annually from the system. If the total loss of 210,000 tonnes per year is subtracted from the solute input found in this study, and from the results of McCarthy and Metcalfe (1990), the remaining solutes, which are available for accumulation in the fan, are 247,400 and 106,900 tonnes per year respectively-a factor of 2.3 difference (Table 3). The results of this study therefore suggest that the contribution of bedload inputs relative to the overall sediment accumulation on the fan is much more important than thought previously.

\section{Results and Discussion: Bedload Transport Modeling}

\section{Distribution and Magnitude of Aggradation Rates}

The hydrological model of the Okavango Delta with activated BLT package was run over the period from 1970 to 2006. Initial channel elevations are extracted from the micro-topographic map derived by Gumbricht et al. (2005). The simulation is therefore a forecast of the channel elevations assuming similar future climate conditions as in the past. The upstream boundary condition of the channel network, the first reach at the inflow in Mohembo, is set to a constant channel base elevation.

The accumulated elevation changes of the channel bases after 37 years of model run (Fig. 9) are minor with few peak values of approximately $0.50 \mathrm{~m}$. The distribution indicates highest rates of elevation change in the Panhandle region where the transport capacity of the channels is the highest contrasting with very stable conditions in the central and south-eastern wetlands.
Table 2 Potential amount of annual deposited mass resulting from a mean inflow of $292 \mathrm{~m}^{3} / \mathrm{s}$ and measured mean ion concentrations

in the form of $22.8 \mathrm{mg} / \mathrm{l}$ of $\mathrm{H}_{4} \mathrm{SiO}_{4}$

\begin{tabular}{llll}
\hline Ion & Mean concentration $[\mathrm{mg} / \mathrm{l}]$ & Deposit & Potential amount of deposit [tonnes/year] \\
\hline $\mathrm{Ca}$ & 3.5 & $\mathrm{CaCO}_{3}$ & 81,300 \\
$\mathrm{Mg}$ & 0.9 & $\mathrm{MgCO}_{3}$ & 29,000 \\
$\mathrm{~K}$ & 2.1 & $\mathrm{~K}_{2} \mathrm{CO}_{3}$ & 33,900 \\
$\mathrm{Na}$ & 1.9 & $\mathrm{Na}_{2} \mathrm{CO}_{3}$ & 41,300 \\
$\mathrm{Si}^{\mathrm{a}}$ & 6.7 & $\mathrm{SiO}_{2}$ & 131,500 \\
& & & Tot.: 316,900 \\
\hline
\end{tabular}


Table 3 Comparison of deposit rates between this and previous studies

\begin{tabular}{llll}
\hline & Previous study & Amount, previous study [tonnes/year] & Amount, this study [tonnes/year] \\
\hline Solutes & (McCarthy and Metcalfe 1990) & 247,400 & 106,900 \\
Suspended load & (McCarthy and Metcalfe 1990) & 30,000 & N.A. \\
Bedload & (McCarthy et al. 1991) & 155,000 & 120,000 \\
Aerosols & (Garstang et al. 1998) & 250,000 & N.A. \\
\hline
\end{tabular}

The simulated elevation changes are relatively small and are probably not much larger than the accuracy of the initial elevations. Not too much importance should therefore be assigned to the small-scale variability of elevation changes. A good identification of larger erosional or aggradational reaches is however possible. Interesting elevation changes can be observed in segments 10 and 22 (labeled in Fig. 9).

Segment 10 (the uppermost section of the Thaoge) is part of the important branching where flows separate into the Thaoge and Jao systems. The high aggradation rate in the beginning of segment 10 is consistent with the failure of flows towards the Thaoge in recent times. During the first year of the simulation, the elevation profile develops into a smoother curve to compensate for what probably are elevation inaccuracies of the input data. The aggradation simulated during the following years is due to a rapid decrease in downstream direction of the transport capacity.

The end of segment 22 (the Maunachira) shows progressive aggradation over the simulation period. The waters of the Maunachira eventually flow into the Khwai, but the linkage of both channels is primarily through floodplains. The Maunachira is therefore simulated without channel connection to downstream channels, and the current channel bed aggradates. The model cannot simulate at what point the current channel will fail, or where a new channel will be induced. With the long time scales involved in channel shifts this would not be feasible because the required computational time for model execution would be too great. Over the time scales for which the model has been developed (few decades), it can be seen that the elevation changes are small enough to justify ignoring channel shifts but concentrate on aggradation and erosion rates.

\section{Impact of Upstream Bedload Retention}

Consequences of a dam upstream of the Okavango Delta are simulated by changing the boundary condition of the most upstream channel reach in the model. By setting it to active, the first reach's channel base elevation changes according to bedload transport to the second reach. The simulation assumes that the dam retains the entire bedload fraction of the sediment transport, and is run over the period from 1970 to 2006. Results show that after 37 years of total bedload retention upstream of the wetlands, the impact on channel base elevations is restricted to the upper part of the Panhandle. The total simulated elevation changes with or without the dam (Figs. 9 and 10) differ noticeably only in a

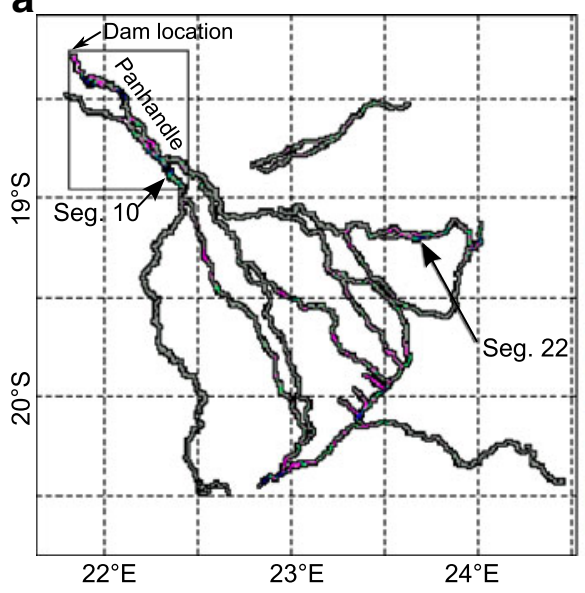

b

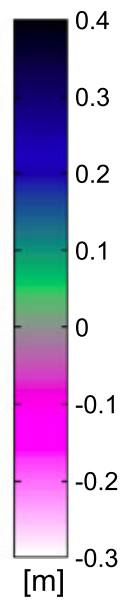

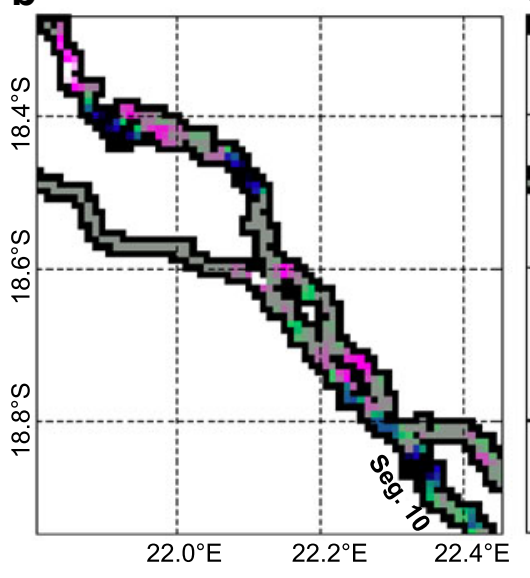

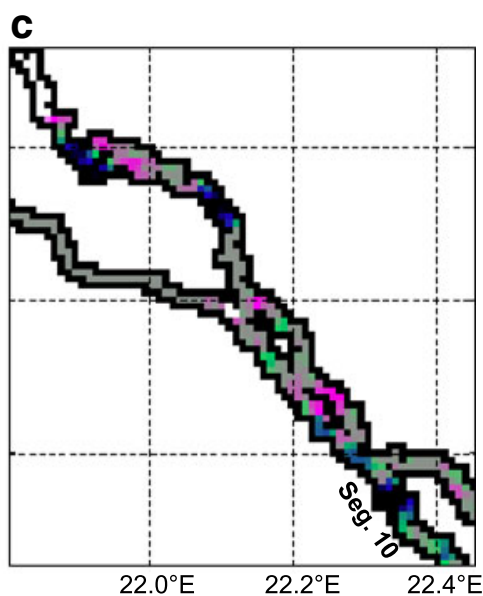

Fig. 9 a Accumulated elevation changes of channel bases over the period from 1970 to 2006 simulated without dam. b Panhandle region subset of the same results for comparison with c), displaying elevation changes in the Panhandle region simulated for the same period with dam 


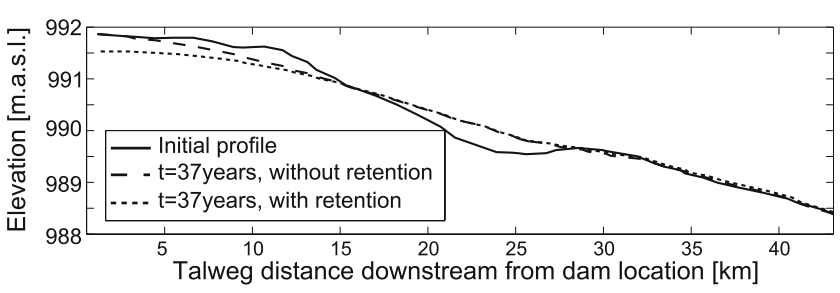

Fig. 10 Longitudinal elevation profile downstream from dam location. Initial profile and profiles after the simulations with and without dam

the first $15 \mathrm{~km}$ downstream of the dam. In initial reaches, the dam induces a lowering of the channel bed profile by approximately $0.4 \mathrm{~m}$.

Despite the fact that elevation changes due to bedload retention are simulated only in the proximal wetland reaches, some impact on the distribution of flooding is observed all over the fan. Obviously there is an impact in the Panhandle region adjacent to where the channel elevations are most affected. The decrease in flooding frequency is up to $10 \%$ in this area after dam construction. The remainder of the Panhandle, however, is virtually unaffected with variations in the flooding frequency being minor except for localized pockets that reach magnitudes similar to those observed immediately downstream of the dam (Fig. 11). Elevation changes in the most upstream wetlands of the Panhandle impact flooding frequency in distal areas. With erosion of the upstream channel, less water is stored in the upstream floodplains. The increased wetted perimeter of the upstream channel creates the potential for increased discharge and reduced lag time. This finding indicates that small changes in elevations at certain key positions in

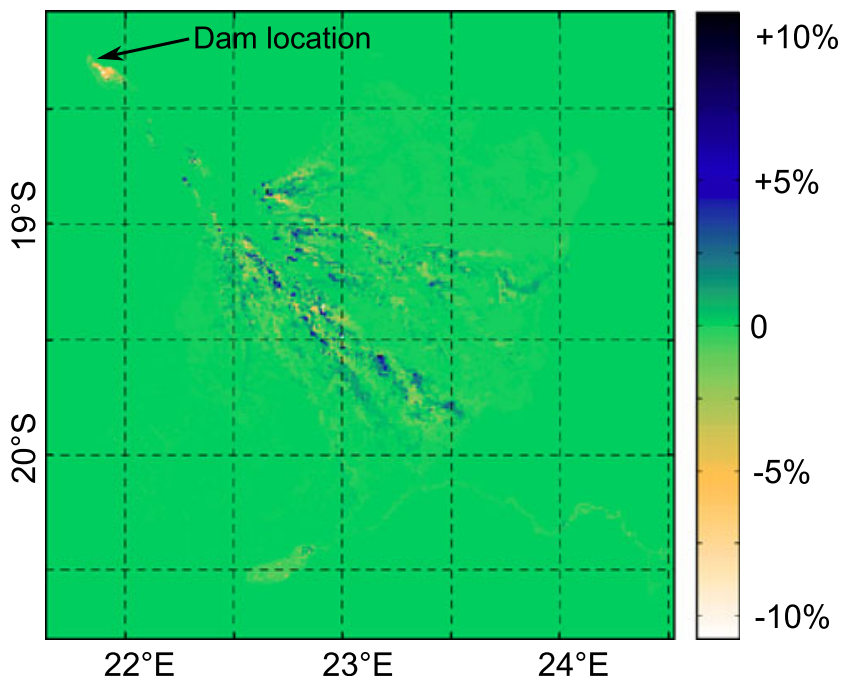

Fig. 11 Impact on the flooding frequency of bedload retention by a dam: differences in flooding frequencies 37 years after the construction of a dam upstream to Mohembo the drainage network can alter the distribution of flooding over the whole fan surface.

\section{Conclusions}

The analysis of water samples taken at the entrance to the Okavango Delta in Mohembo revealed a pronounced seasonality in concentrations of ions and dissolved silica. Concentrations are found to be lower than in a previous study by McCarthy and Metcalfe (1990). After subtraction of solute outputs from the overall aquifer-wetland system the relative difference is considerable. We conclude that 2.3 times less dissolved load remain in the system. The portion of the overall sediment accumulation that can be attributed to bedload inputs is therefore found to be considerably higher than in previous studies.

The bedload transport measurements carried out in collaboration with the Department of Water Affairs of Botswana (DWA) yielded results that build on the earlier findings of the Okavango Research Group at the University of the Witwatersrand in South-Africa (Prof. T. S. McCarthy and co-workers). From the bedload transport measurements made at several stations and during variable flow conditions, a flow-transport rating curve was established, which is similar to that of McCarthy et al. (1992), but describes lower transport rates for typical flow conditions of the Okavango Delta channels. The study also covers a larger range of discharge.

The implementation of bedload transport into the MODFLOW model using the observed rating curve was achieved by programming a new bedload transport package that interacts with the SFR2 stream flow routing package of MODFLOW. It is shown that current erosion and aggradation rates of channel beds are generally very low, increasing to $0.014 \mathrm{~m} /$ year for specific short channel sections. The simulation of an upstream dam retaining all bedload revealed no impact on channel bed elevations except for the most proximal $15 \mathrm{~km}$. In this stretch, flooding frequency was found to decrease by approximately $10 \%$. The bed elevation changes in the upstream stretch cause hydrograph changes that subsequently induce both positive and negative changes in flooding frequency over the entire wetlands amounting to a few percent with isolated locations showing changes of up to $10 \%$.

Acknowledgments We thank T. McCarthy for his valuable advice on the practical aspect of bedload monitoring, D. Braun and M. Hanyecz for the solute analyses, and the Department of Water Affairs Botswana for fieldwork logistics. This research has been supported financially by the Swiss National Science Foundation under project $\mathrm{Nr}$ 200021-105384. We thank Rob Hillier and an anonymous referee for valuable suggestion given in the review of the manuscript. 


\section{References}

Bauer P, Gumbricht T, Kinzelbach W (2006) A regional coupled surface water/groundwater model of the Okavango Delta, Botswana. Water Resources Research 42:15

Bran + Luebbe (1999) AutoAnalyzer Applications, AutoAnalyzer Method No. G-177-96 Silicate in Water and Seawater, Bran Luebbe, Inc., Buffalo Grove, IL

Bridge JS (2003) Rivers and floodplains: forms, processes, and sedimentary record. Blackwell Science, London

Dincer T, Child S, Khupe B (1987) A simple mathematical-model of a complex hydrologic system-Okavango Swamp, Botswana. Journal of Hydrology 93:41-65

Dincer T, Heemmsra HH, Kraatz DB (1976) The study of hydrological conditions in an experimental area in the seasonal swamp. Tech. Note No. 20, UNDP FAO, BOT/71/506

Dincer T, Hutton LG, Kupee BBJ (1978) Study, using stable isotopes, of flow distribution, surface-groundwater relations and evapotranspiration in the Okavango Swamp, Botswana I.A.E.A. Symposium on Isotope Hydrology. Vol. 493. STI/PUB, Neuherberg, Germany, pp 3-26

Einstein HA (1950) The bedload function for sediment transportation in open channels. US Dept Agric Soil Conserv Serv Techn Bull 1026

Ellery WN, Ellery K, Rogers KH, McCarthy TS (1995) The role of cyperus-papyrus in channel blockage and the abandonment in the northeastern Okavango Delta, Botswana. African Journal of Ecology 33:25-49

Ellery WN, McCarthy TS (1998) Environmental change over two decades since dredging and excavation of the lower Boro River, Okavango Delta, Botswana. Journal of Biogeography 25:361-378

Ellery WN, McCarthy TS, Smith ND (2003) Vegetation, hydrology, and sedimentation patterns on the major distributary system of the Okavango Fan, Botswana. Wetlands 23:357-375

Garstang M, Ellery WN, McCarthy TS, Scholes MC, Scholes RJ, Swap RJ, Tyson PD (1998) The contribution of aerosol- and water-borne nutrients to the functioning of the Okavango Delta ecosystem, Botswana. South African Journal of Science 94:223229

Gumbricht T, McCarthy TS, Bauer P (2005) The micro-topography of the wetlands of the Okavango Delta, Botswana. Earth Surface Processes and Landforms 30:27-39

Harbaugh AW, Banta ER, Hill MC, McDonald MG (2000) MODFLOW-2000, the U.S. Geological Survey modular ground-water model-User guide to modularization concepts and the Ground-Water Flow Process. U.S. Geological Survey Open-File Report 00-92, $121 \mathrm{pp}$

Kgotlhang L, Milzow C, Kinzelbach W (2006) Aero-geophysical remote sensing to generate input data for a distributed hydrological model of the Okavango Delta, Botswana. Proceedings of the GlobWetland symposium, 19-20 Oct. 2006, Frascati, Italy

Lancaster IN (1979) Evidence for a widespread late Pleistocene humid period in the Kalahari. Nature 279:145-146

Lindholm M, Hessen DO, Mosepele K, Wolski P (2007) Food web and the energy fluxes on a seasonal floodplain: The influence of flood size. Wetlands 27:775-784

McCarthy TS, Metcalfe J (1990) Chemical sedimentation in the semiarid environment of the Okavango Delta, Botswana. Chemical Geology 89:157-178

McCarthy TS, Ellery WN, Rogers KH, Cairncross B, Ellery K (1986) The roles of sedimentation and plant-growth in changing flow patterns in the Okavango Delta, Botswana. South African Journal of Science 82:579-584

McCarthy TS, Stanistreet IG, Cairncross B, Ellery WN, Ellery K, Oelofse R, Grobicki TSA (1988) Incremental aggradation on the Okavango Delta-fan, Botswana. Geomorphology 1:267-278

McCarthy TS, Stanistreet IG, Cairncross B (1991) The sedimentary dynamics of active fluvial channels on the Okavango Fan, Botswana. Sedimentology 38:471-487

McCarthy TS, Ellery WN, Stanistreet IG (1992) Avulsion mechanisms on the Okavango Fan, Botswana - the control of a fluvial system by vegetation. Sedimentology 39:779-795

McCarthy TS, Green RW, Franey NJ (1993) The influence of neotectonics on water dispersal in the northeastern regions of the Okavango Swamps, Botswana. Journal of African Earth Sciences 17:23-32

Meyer-Peter E, Müller R (1948) Formulas for bedload transport. Paper presented at proc. 2nd Meeting Intl. Ass. Hyd. Structures Res. Stockholm, Sweden

Milzow C (2008) Hydrological and sedimentological modelling of the Okavango Delta Wetlands, Botswana. PhD thesis ETH Zurich, Switzerland. http://e-collection.ethbib.ethz.ch/view/eth:31163

Milzow C, Kgotlhang L, Kinzelbach W, Meier P, Bauer-Gottwein P (2009) The role of remote sensing in hydrological modelling of the Okavango Delta, Botswana. Journal of Environmental Management 90:2252-2260

NamPower (2003) Pre-feasibility study for the popa falls hydro power project, Preliminary Environmental Assessment, Executive Summary. http://www.nampower.com.na/docs/Executive\%20Summary1. pdf (accessed 13.10.09)

Niswonger RG, Prudic DE (2005) Documentation of the Streamflowrouting (SFR2) Package. U.S. Geological Survey Technical Methods, Book 6, Chapter A13, 47 pp

Pike JG (1970) Iterim technical notes on the hydrology and water resources of the Okavango River system. UNDP/FAO/Botswana government. Surveys and training for the development of water resources and agricultural production, Botswana. Technical Note no. 5

Ramberg L, Hancock P, Lindholm M, Meyer T, Ringrose S, Sliva J, Van As J, VanderPost C (2006a) Species diversity of the Okavango Delta, Botswana. Aquatic Sciences 68:310-337

Ramberg L, Wolski P, Krah M (2006b) Water balance and infiltration in a seasonal floodplain in the Okavango Delta, Botswana. Wetlands 26:677-690

Reeves CV (1972) Rifting in Kalahari. Nature 237:95-96

Sefe FTK (1996) A study of the stage-discharge relationship of the Okavango River at Mohembo, Botswana. Hydrological Sciences Journal-Journal Des Sciences Hydrologiques 41:97-116

UNESCO (1971) Convention on Wetlands of International Importance especially as Waterfowl Habitat. Ramsar (Iran), 2 February 1971. UN Treaty Series No. 14583. As amended by the Paris Protocol, 3 December 1982, and Regina Amendments, 28 May 1987

Wolski P, Murray-Hudson M (2006) Flooding dynamics in a large low-gradient alluvial fan, the Okavango Delta, Botswana, from analysis and interpretation of a 30-year hydrometric record. Hydrology and Earth System Sciences 10:127-137

Wolski P, Savenije HHG (2006) Dynamics of floodplain-island groundwater flow in the Okavango Delta, Botswana. Journal of Hydrology 320:283-301

Wolski P, Murray-Hudson M (2008) An investigation of permanent and transient changes in flood distribution and outflows in the Okavango Delta, Botswana. Physics and Chemistry of the Earth 33:157-164 